\title{
HoReCa Food Waste and Sustainable Development Goals-A Systemic View
}

\author{
Aleksander Buczacki ${ }^{1, *(D)}$, Bartłomiej Gładysz ${ }^{1}\left[\right.$ and Erika Palmer ${ }^{2}$ \\ 1 Faculty of Production Engineering, Warsaw University of Technology, 02-524 Warszawa, Poland; \\ bartlomiej.gladysz@pw.edu.pl \\ 2 Sintef Ocean, N-7010 Trondheim, Norway; erika.palmer@sintef.no \\ * Correspondence: aleksander.buczacki@pw.edu.pl; Tel.: +48-22-234-8126
}

check for updates

Citation: Buczacki, A.; Gładysz, B.; Palmer, E. HoReCa Food Waste and Sustainable Development Goals-A Systemic View. Sustainability 2021, 13, 5510. https://doi.org/10.3390/ su13105510

Academic Editor: Michael Carolan

Received: 13 April 2021

Accepted: 13 May 2021

Published: 14 May 2021

Publisher's Note: MDPI stays neutral with regard to jurisdictional claims in published maps and institutional affiliations.

Copyright: (c) 2021 by the authors. Licensee MDPI, Basel, Switzerland. This article is an open access article distributed under the terms and conditions of the Creative Commons Attribution (CC BY) license (https:// creativecommons.org/licenses/by/ $4.0 /)$.

\begin{abstract}
A significant share of food waste originates in the food services domain and HoReCa sector. Organizational improvements leading to the decrease of food waste and related costs in HoReCa are needed to make progress in this issue. A systems engineering approach was applied to examine the links between food waste generated in the HoReCa industry and the Sustainable Development Goals (SDGs). A literature review discovered two dimensions of actions leading to decreasing food waste in HoReCa; i.e., actions triggered by companies and by authorities (e.g., governmental policies). Additionally, customers and society were also considered. A framework is proposed to explicitly illustrate the dependencies of different micro actions devoted to food waste reduction in HoReCa in support of the SDGs. The other dimension of this framework is macro policies and their impact on SDGs. To increase food waste reduction awareness and collaboration, stakeholders on both the macro (launched by authorities for the whole sector) and micro (initiated by single organizations on their own) levels must work together. The results of this research will be useful in coordinating the efforts of all (consumers, HoReCa companies and suppliers, policymakers and administrations on different levels) involved in the supply chain of food production and consumption.
\end{abstract}

Keywords: food waste; food services; HoReCa; Sustainable Development Goal; regional policy

\section{Introduction}

Sluggish progress towards the targets of the 17 Sustainable Development Goals (SDGs) suggests that there is an urgent need to consider new approaches that clarify their interrelationships while also accounting for both their complexity and their sometimes mutually reinforcing or conflicting objectives. Attempting to achieve them in a linear succession is impossible, but pursuing them simultaneously is impractical [1].

Researchers from developed countries (USA and Europe) have been interested in food waste (FW) reduction, also recycling and prevention, since the 1910s [2,3]. In the past, the main focus was on waste disposal, but from the early 1980s, the awareness of the importance of FW prevention and reduction arose again [4,5]. Food is wasted along the entire food chain, starting from farms, plantations and fisheries, through processing facilities, transportation, distribution sites, retail establishments, restaurants and homes [6,7]. In the supply chain, from harvesting to the processing stage, $13.8 \%$ of food is wasted [8]. A significant share of food waste is generated in the food services industry, including restaurants, bars, bistros, fast food chains, catering, etc. It is estimated that about $7 \%$ of food is wasted in US restaurants before the consumer is served [9], and as determined for 2012, about $12 \%$ of food is wasted in the food service industry in the European Union [10]. For effective FW management in HoReCa (hotels, restaurants, catering), consumers' habits should be considered along with additional stakeholder activities [11,12]. Typical sources of FW are oversized portions [13], inflexibility of chain store management, extensive menu choices [9], and meals served mistakenly or delayed. According to research results conducted in selected European countries, on average $20 \%$ of meals are wasted in the hospitality sector [14]. 
Sustainable Development Goal 12 has a target that addresses these statistics, namely, 12.3, which states, "By 2030, halve per capita global food waste at retail and consumer levels and reduce food loses along production and supply chains, including post-harvest losses [15]."

There are a number of studies focused on companies' operational efficiency from the HoReCa sector that consider food waste on the micro (company) level, also taking into account the macro level, but without an SDG context. However, there is research focused on food waste on regional, country or event global (macro) levels that considers different SDGs and their indicators [15]. There is currently a lack of research with an integrative view considering both micro (organization) and macro (policymakers and economies) levels, and the SDG implementation perspective. Due to this, the main objective of this paper is a proposal for food waste reduction practice integration on micro and macro levels in the case of SDG objectives management using a systems engineering approach. In using a systems engineering approach, we apply systems thinking to food waste in HoReCa in an SDG context. In addition to developing a proposal, we place the results of this study into a larger discussion of how using a systems engineering approach addresses criticism of SDG targets in general using HoReCa as an example.

We begin this paper with an explanation of how we conducted the systematic literature review, and then we present the results in Section 3 in a systems engineering context. We conclude this study with a discussion of how a systems engineering approach can foster progress towards SDG targets. This paper provides an overview of dependencies between different SDGs from a food waste reduction point of view. It also provides an introduction to available practices for HoReCa businesses, with consideration of their own actions as well as authority-driven programs. The goal is, therefore, twofold, i.e.,

- To develop a conceptual causal loop diagram for food waste in the HoReCa sector;

- To develop a conceptual causal loop diagram for SDGs' support from HoReCa best practices on food waste.

\section{Materials and Methods}

For this research, the following systematic literature review research methodology was implemented. First, the following queries (for article title, abstract and keywords) in WoS and Scopus databases were performed:

(1) "Food waste" AND (HoReCa OR Hospitality OR "food service")

(2) "Food waste" AND "Sustainable Development Goals"

Hospitality and the food sector were included in the query, as the term "HoReCa" is not often used in publications on hotel, restaurant and catering operations. In the next step, only papers in WoS in English without date limits, related to environmental sciences, environmental engineering, green sustainable science technology, environmental studies, nutrition dietetics, management, business, economics, behavioral sciences and operations research management science were considered. In Scopus, only papers in English without date limits, related to environmental sciences, business, management and accounting, social sciences, economics, econometrics and finance and decision sciences were considered. Through abstract analysis, papers related to technical questions were excluded.

Only papers from 2015 to the present in English have been taken into consideration because the SDGs were accepted by the UN in 2015. The majority of the papers for the Food Waste AND SDG query focused on the circular bioeconomy and effective energy management, which are not relevant for this research. The second group of papers focused on technical questions. Some of the papers focused on recycling in general, not related to the HoReCa sector and FW reduction practices, so such papers were also not taken into consideration.

Finally, only papers related to food waste and HoReCa and related with HoReCa (hospitality and food service sectors) have been taken into further analysis (Table 1). 
Table 1. Number of papers analyzed in particular steps.

\begin{tabular}{cccc}
\hline Sample Characteristics & WoS & Scopus & WoS + Scopus with No \\
Repetitions
\end{tabular}

Selected papers have been analyzed according to the level of food waste practices:

- Company level (micro)—closely related to companies' operational activities and customer behavior.

- Policymakers at regional, national or global level (macro)—related to polices and regional, national or global programs.

Best practices on the micro level, and in particular related to restaurants, have been identified. Preliminary impact of the identified best practices has been assessed.

Concurrently, best practices implemented by local, regional and national authorities as well as by international organizations and related to food waste appropriate SDGs have been identified. Later, relationships were analyzed separately for best practices on the macro level and the SDG focus. Finally, based on the analysis results, we developed the integrated framework. Figure 1 illustrates the research methodology.

\section{State-of-the-art:}

food waste in HoReCa companies (micro)

SDGs related with food waste (micro and macro)

- Defining databases and query, inclusion and exclusion criteria

- Abstract screening

- Review of selected papers

- Inclusion of new papers as found in references of selected papers

- Is further investigation of interest?

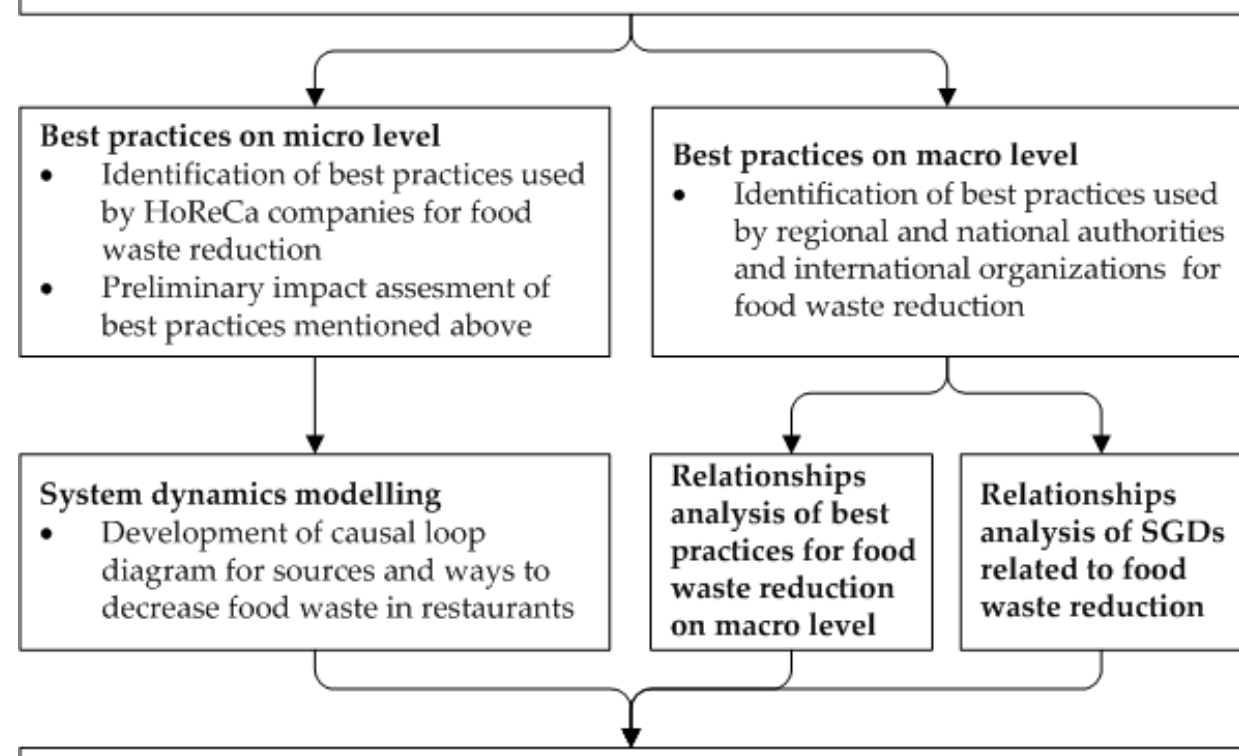

Development of an integrative framework for food waste reduction

Figure 1. Research methodology. Source: authors' elaboration. 


\section{Results}

\subsection{Queries Review Results}

The tables below present the literature review results of two queries:

1. FW AND HORECA (Table 2), with year of publication and whether it concerns good practices addressed on the micro and macro level entities of both.

2. FW AND SDGs (Table 3), with year of publication and which SDGs the publication concerns. Additionally, the tables indicate whether the best practices described in the publication related to the micro and macro levels and entities of both.

Table 2. Summary of papers on food waste (FW) and hotels, restaurants and catering (HoReCa).

\begin{tabular}{|c|c|c|c|c|}
\hline \multirow{2}{*}{ Ref. } & \multirow{2}{*}{ Year } & \multicolumn{2}{|c|}{ Level } & \multirow{2}{*}{ Summary } \\
\hline & & Micro & Macro & \\
\hline [16] & 2021 & $X$ & & $\begin{array}{l}\text { Analysis of responses from } 206 \text { managers of Brazilian food service companies. Findings } \\
\text { focused on FW reduction. }\end{array}$ \\
\hline [17] & 2021 & & $X$ & $\begin{array}{l}\text { Presentation of sociodemographic and food consumption-related factors generated by } \\
\text { tourists in the HoReCa sector. Insights into achieving sustainability objectives in national } \\
\text { and international tourism sectors. }\end{array}$ \\
\hline [18] & 2020 & $X$ & & $\begin{array}{l}\text { Description of best practices implemented by } 3 \text { HoReCa companies based on lean } \\
\text { management approach and its impact on FW reduction. }\end{array}$ \\
\hline [19] & 2020 & $X$ & $x$ & $\begin{array}{l}\text { Description of multi-stakeholder partnership program "Food waste Challenge", involving } \\
172 \text { restaurants. Program focuses on a range of behavioral interventions. }\end{array}$ \\
\hline [20] & 2020 & $X$ & $X$ & $\begin{array}{l}\text { Paper focuses on the lifecycle assessment of } 15 \text { tapas meals, as well as analysis of } \\
\text { nutritional quality of the meals and energy efficiency at the restaurant. }\end{array}$ \\
\hline [21] & 2020 & & $x$ & Analysis of social, economic and environmental impact of food waste reduction activities. \\
\hline [22] & 2020 & & $X$ & $\begin{array}{l}\text { Analysis of restaurant food waste management practices in the UK and the Netherlands in } \\
\text { case of FW management. }\end{array}$ \\
\hline [23] & 2020 & $\mathrm{X}$ & & $\begin{array}{l}\text { Findings for food waste measurement and waste reduction strategies in the different } \\
\text { stages (pre-kitchen, in-kitchen and post-kitchen). Results based on the survey of almost } \\
500 \text { HoReCa managers. }\end{array}$ \\
\hline [24] & 2020 & $\mathrm{X}$ & & $\begin{array}{l}\text { Results of semi-structured interviews with } 32 \text { hotel employees and managers. Proposition } \\
\text { of possible strategies for reducing FW addressed for restaurants and consumers. }\end{array}$ \\
\hline [25] & 2019 & $\mathrm{X}$ & & $\begin{array}{l}\text { Evaluation of interventions in two university canteens on their effectiveness to reduce } \\
\text { visitors' plate waste. }\end{array}$ \\
\hline [14] & 2019 & $\mathrm{X}$ & $\mathrm{X}$ & $\begin{array}{l}\text { Empirical evidence for FW reduction in HoReCa sector in Malaysia. Proposition of FW } \\
\text { prevention strategies related to companies' operations activities and consumers' } \\
\text { social practices. }\end{array}$ \\
\hline [26] & 2019 & $\mathrm{X}$ & $\mathrm{X}$ & $\begin{array}{l}\text { Analysis of direct-weighing data (from } 164 \text { restaurants) and its ecological footprint rather } \\
\text { on macro-level. }\end{array}$ \\
\hline [27] & 2019 & $X$ & $X$ & $\begin{array}{l}\text { A case study of the restaurant activity in Bulgaria. Proposition of training programs for } \\
\text { restaurateurs and public authorities. }\end{array}$ \\
\hline [28] & 2019 & & $x$ & $\begin{array}{l}\text { Presentation of research results for the quantification of food waste based on the data } \\
\text { hospitality sector ( } 1189 \text { kitchens) in Sweden, Norway, Finland and Germany. Proposition } \\
\text { of statistical measures for food waste tracking }\end{array}$ \\
\hline [29] & 2018 & & $X$ & Insights of food waste generation factors in HoReCa sector at the national level. \\
\hline [30] & 2018 & $\mathrm{X}$ & & $\begin{array}{l}\text { Identification of waste management initiatives in the food service sector and evaluation of } \\
\text { management practices for waste reduction by managers from food service } \\
\text { sector companies. }\end{array}$ \\
\hline [31] & 2017 & $\mathrm{X}$ & & $\begin{array}{l}\text { Analysis based on managerial opinions of the role of menu design in shaping more } \\
\text { responsible consumer choice and its impact on FW prevention. }\end{array}$ \\
\hline
\end{tabular}


Table 2. Cont.

\begin{tabular}{|c|c|c|c|c|}
\hline \multirow{2}{*}{ Ref. } & \multirow{2}{*}{ Year } & \multicolumn{2}{|c|}{ Level } & \multirow{2}{*}{ Summary } \\
\hline & & Micro & Macro & \\
\hline [32] & 2017 & $\mathrm{X}$ & $\mathrm{X}$ & $\begin{array}{l}\text { Analysis based on } 315 \text { questionnaires from Italian HoReCa SMEs operating in the tourism } \\
\text { sector. Presenting general strategies for both levels micro (company) and macro (regional } \\
\text { authorities and commercial chambers). }\end{array}$ \\
\hline [33] & 2016 & $\mathrm{X}$ & & $\begin{array}{l}\text { Research results of the management staff of } 45 \text { restaurants/hotels. Proposition of } \\
\text { strategies that involve the cooperation of the restaurant/hotel staff and the guests. }\end{array}$ \\
\hline [34] & 2015 & $X$ & & Presentation of a case study and implications and impact on prevention. \\
\hline
\end{tabular}

Table 3. Summary of papers on FW and sustainable development goals.

\begin{tabular}{|c|c|c|c|c|c|}
\hline \multirow{2}{*}{ Ref. } & \multirow{2}{*}{ Year } & \multicolumn{2}{|c|}{ Level } & \multirow{2}{*}{ SDGs } & \multirow{2}{*}{ Summary } \\
\hline & & Micro & Macro & & \\
\hline [35] & 2021 & & $X$ & 12.3 & $\begin{array}{l}\text { Review of the food waste scenario, adverse effects, food waste policies and } \\
\text { regulations in Bangladesh on national and municipalities levels. }\end{array}$ \\
\hline [36] & 2021 & $x$ & $x$ & 12.3 & $\begin{array}{l}\text { Statistical analysis of } 46 \text { food waste items generated by households in the } \\
\text { Buk-gu province of Daegu, South Korea. }\end{array}$ \\
\hline [37] & 2021 & $x$ & & 12.3 & $\begin{array}{l}\text { Presentation of case study: primary school (in Valencia) pupils' behavior } \\
\text { change after intervention focused on food waste reduction (knowledge, } \\
\text { awareness, attitudes). }\end{array}$ \\
\hline [38] & 2020 & & $x$ & 12.3 & $\begin{array}{l}\text { Presentation of additional value of citizen science as a trigger for policy } \\
\text { making on behavior change. }\end{array}$ \\
\hline [39] & 2020 & & $X$ & $1,2,6,12,13$ & $\begin{array}{l}\text { Estimation of carbon and water footprint of food. Comparison of the } \\
\text { values of environmental footprint in the case of rational consumption } \\
\text { of meat. Presentation of evaluation-obtained results by chemical } \\
\text { engineering students. }\end{array}$ \\
\hline [19] & 2020 & $x$ & $x$ & 12,17 & $\begin{array}{l}\text { Description of multi-stakeholder partnership program "Food waste } \\
\text { Challenge" involving } 172 \text { restaurants. Program focuses on a range of } \\
\text { behavioral interventions. }\end{array}$ \\
\hline [40] & 2020 & $x$ & & 12.3 & $\begin{array}{l}\text { Study of Covid-19 pandemic impact on food waste generation, financial } \\
\text { costs and nutritional losses in Italian households. }\end{array}$ \\
\hline$[41]$ & 2020 & $\mathrm{X}$ & & 12.8 & Study of 19 passengers from 21 full-service flights. \\
\hline [42] & 2020 & & $x$ & $\begin{array}{c}1.2,1.3,3.4,4.7,7.2 \\
8.2,8.5,9.4,11.6 \\
12.3,12.5,13.3 \\
17.16,17.17\end{array}$ & $\begin{array}{l}\text { Food waste policy analysis provided by } 40 \text { cities across } 16 \text { European } \\
\text { countries. Links between different types of policies provided and their } \\
\text { impact on selected SDGs. }\end{array}$ \\
\hline [21] & 2020 & & $X$ & 12 & $\begin{array}{l}\text { Analysis of social, economic and environmental impact of food waste } \\
\text { reduction activities. }\end{array}$ \\
\hline [43] & 2020 & & $x$ & $2,3,8$ & $\begin{array}{l}\text { Presentation of the interrelations between SDGs, food access and waste } \\
\text { also in the case of COVID-19 pandemic conditions. }\end{array}$ \\
\hline [44] & 2020 & $x$ & $x$ & & $\begin{array}{l}\text { Presentation of quantification methodology of food waste in Swedish } \\
\text { hospitals. Different types of waste defined (serving waste, plate waste, } \\
\text { kitchen waste). }\end{array}$ \\
\hline [45] & 2020 & & $x$ & 12.3 & $\begin{array}{l}\text { Results of research (in } 2016 \text { and 2019) of } 165 \text { Hungarian households based } \\
\text { on FUSIONS methodology. }\end{array}$ \\
\hline [46] & 2020 & $x$ & $x$ & 12.3 & $\begin{array}{l}\text { Presentation of research results on the application of different types of } \\
\text { awareness techniques (passive approach (handouts), community } \\
\text { engagement approach and gamification for } 501 \text { households. }\end{array}$ \\
\hline
\end{tabular}


Table 3. Cont.

\begin{tabular}{|c|c|c|c|c|c|}
\hline \multirow{2}{*}{ Ref. } & \multirow{2}{*}{ Year } & \multicolumn{2}{|c|}{ Level } & \multirow{2}{*}{ SDGs } & \multirow{2}{*}{ Summary } \\
\hline & & Micro & Macro & & \\
\hline [47] & 2019 & $X$ & $X$ & 12.3 & $\begin{array}{l}\text { Presentation of research using different approaches for } \\
\text { self-reporting-passive (offline), proactive (online)—and evaluation of } \\
\text { both approaches in case of food waste reduction. }\end{array}$ \\
\hline [48] & 2019 & & $x$ & 12.3 & $\begin{array}{l}\text { Results of supply chain analysis, including production, consumption and } \\
\text { utilization per different food groups according to the food waste reduction. }\end{array}$ \\
\hline [49] & 2019 & & $x$ & 12.3 & $\begin{array}{l}\text { Results of questionnaire-based research in the UK. Based on the } \\
\text { proposition of categorization of what is considered edible in the case of the } \\
\text { quantification of food waste. }\end{array}$ \\
\hline [28] & 2019 & & $x$ & 12.3 & $\begin{array}{l}\text { Presentation of research results for the quantification of food waste based } \\
\text { on the data hospitality sector ( } 1189 \text { kitchens) in Sweden, Norway, Finland } \\
\text { and Germany. Proposition of statistical measures for food waste tracking. }\end{array}$ \\
\hline [50] & 2019 & $X$ & & 12.3 & $\begin{array}{l}\text { Results of the analysis of } 411 \text { individuals from central Italy. Identification } \\
\text { of support programs related to FW awareness, business investment in } \\
\text { innovations and digital solutions focused on FW reduction. }\end{array}$ \\
\hline [51] & 2019 & & $X$ & 12.3 & $\begin{array}{l}\text { A footprint analysis of the food loss at the stage of vegetable production in } \\
\text { Japan. Proposition of actions helping farmers to make a crop production } \\
\text { and distribution plan. }\end{array}$ \\
\hline [52] & 2019 & & $X$ & $2,12.3$ & $\begin{array}{l}\text { Proposition of the actions of food and nutrition security for supporting } \\
\text { developing countries. }\end{array}$ \\
\hline [53] & 2019 & $X$ & $x$ & & $\begin{array}{l}\text { Presentation of study results of } 680 \text { Danish canteens related to nutrition } \\
\text { and service management focused on food waste reduction. }\end{array}$ \\
\hline [54] & 2019 & $X$ & $X$ & 12.3 & $\begin{array}{l}\text { Review of interventions focused on food waste reduction in the hospitality } \\
\text { sector and society (relating to nutrition behaviors). }\end{array}$ \\
\hline [55] & 2018 & & $X$ & 12.3 & $\begin{array}{l}\text { Brief description of UK program designed to prevent food waste } \\
\text { generation in the hospitality and food service sector launched in } 2017 .\end{array}$ \\
\hline [56] & 2018 & & $X$ & 12.3 & $\begin{array}{l}\text { Review of studies on food waste generation at the global and } \\
\text { European scales. }\end{array}$ \\
\hline [30] & 2018 & $x$ & & & $\begin{array}{l}\text { Identification of waste management initiatives in the food service sector } \\
\text { and evaluation of management practices for waste reduction by managers } \\
\text { from food service sector companies. }\end{array}$ \\
\hline [57] & 2018 & $X$ & $X$ & 12 & $\begin{array}{l}\text { Study of middle school students from } 11 \text { Polish schools. Analysis of food, } \\
\text { nutrient, and energy waste and its impact on households' food waste and } \\
\text { nutrition and energy losses. }\end{array}$ \\
\hline [58] & 2015 & $X$ & $X$ & & $\begin{array}{l}\text { Presentation of } 17 \text { interview results with } 17 \text { Swedish food } \\
\text { retailer representatives. }\end{array}$ \\
\hline
\end{tabular}

\subsection{Best Practices on the Micro Level}

As mentioned, practices on the micro level are related to the ways HoReCa companies operate and consumer behavior. Analysis of the HoReCa companies may include three phases: pre-kitchen (FW in warehouse, storage before meal preparation), in-kitchen (FW during meal preparation) and post-kitchen (FW on plate). Food waste generated in pre-kitchen and in-kitchen phases largely depends on company business practice and supplier engagement. Food waste generated in the post-kitchen phase depends mainly on consumer behavior.

According to Vizzoto et al. [23], companies should focus on constantly revising the dishes offered in the menu, reduction of overcooking, creative reproduction, donations to staff/charity organizations, offering options of ordering smaller portions (e.g., for kids) and marketing actions. In general for waste reduction, many companies use the following types of actions [24,59]: measuring, engaging staff, reducing overproduction, rethinking in- 
ventory and purchasing practices, and repurposing excess food. For food waste reduction, there could also be the utilization of management practices, which are common in manufacturing companies. Gladysz at al. [18] examined the application of lean management practices and found the following to be most useful: 5S (technique for station organization), new layout design, Kanban (technique for process flow management), Gemba walk (technique for process analysis), TWI (training within industry) job instructions, standardization, visual management, personnel motivational system, matrix of competences and a suggestion system. To have a complete picture of the best practices in HoReCa, companies focused on food waste reduction should also account for the impact of suppliers and consumer behavior. According to da Rosa et al. [16], FW reduction activities should be focused on innovations in the planning of menus, purchases and process of food preparation. Local suppliers usually can react more flexibly and respond quicker to changes in demand. Especially in the tourism sector, there is an additional advantage of cooperation with local suppliers [32]. Better understanding of customer needs also has an impact on food waste reduction; e.g., extension of lunch breaks from 20 to $30 \mathrm{~min}$ in middle schools resulted in a reduction of plate leftovers [57].

Secondi et al. [50] suggested that the use and implementation of smart applications and digital solutions can support additional studies on out-of-home food waste from a multiple stakeholder perspective, to better understand the amount of FW generated in this part of the food supply chain and multi-stakeholder collaboration along the entire food supply chain [60].

After analysis of the best practices, the authors considered the value of capturing the dynamics surrounding food waste in the HoReCa sector in a causal loop diagram (CLD). Analysis of three HoReCa case studies conducted in Poland provided the rich details used to derive this diagram [17]. A causal loop diagram is a useful visualization of how different elements are interrelated. The diagram consists of a set of nodes and edges. Nodes represent the elements and edges are the links that represent a connection or a relation between them. Thus, if you consider the diagram in Figure 2, FoodWaste is placed at the center of the diagram. The research has indicated that the source of this waste comes from OutdatedFood and PlateLeftovers, which in turn are affected by the SizeOfMeals. Additional information about creating CLDs is abundantly available [61,62], and this diagram was generated using the AnyLogic8.2 software.

TotalDistancePerMeal is the total travel distance from stock of ingredients to customer plate. The greater Space, the greater this distance. Space in this model is used to mean overall space, including storage of ingredients, storage of leftovers, storage of meals to be served and meals in progress, but it also means space in the guestroom. Sales is mostly related to difficulties in planning due to the uncertainty of the number of guests. Those issues lead to fluctuations in other entities in the CLD, like IngredientsStocks that are linked with NumberOfMeals. The more complex is the meal (NumberOfOperationsPerMeal and OperationsCycleTimes), the longer the lead time from ordering to serving the meal to a customer (ServingLeadTime). The lead time is also growing with an increase in total distance (transportation) per meal. On the other hand, lead time is also growing if batches (CookingBatches) are increasing. The greater the batches, the bigger the stocks of ingredients are needed. From this point, one can see that increase of stock directly leads to outdated food (OutdatedFood), which is a kind of food waste itself. In the bottom part of CLD, the loops for leftovers are represented. The greater the Sales, the more EdibleLeftovers. Actions that should directly address EdibleLeftovers, and therefore, the more EdibleLeftovers, the greater need for these actions are transforming Edible into ReprocessedLeftovers, delivering DonationsToCharity, and serving Staffmeals from EdibleLeftovers. All those actions lead to a final decrease in the total FoodWaste. Additionally, it is important to decrease FoodWaste through customer behavior and encourage them to take PlateTakeovers (LeftoversTakenByCustomer decreasing total FoodWaste). Importantly, PlateLeftovers themselves increase with the SizeOfMeals. On the contrary to actions decreasing total FoodWaste (action leading to an increase of ReprocesedLeftovers, DonationsToCharity, 
StaffMeals, LeftoversTakenByCustomer), there are factors that increase total FoodWaste, i.e., NonEdibleLeftovers and PlateLeftovers.

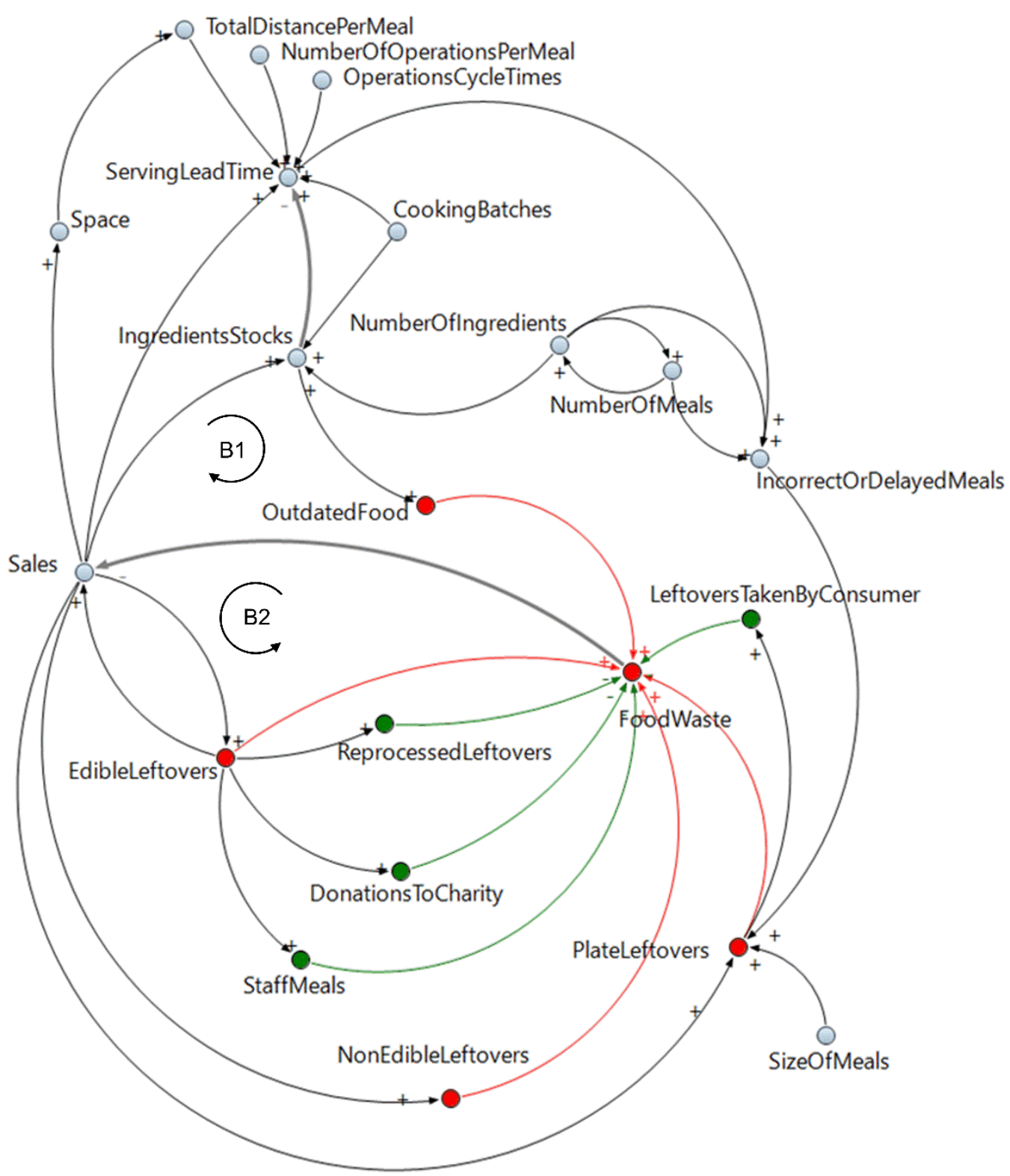

Figure 2. Conceptual causal loop diagram for food waste in HoReCa sector (drawn in AnyLogic8.2): Red points and arrows indicate a positive reinforcing effect, i.e., increased food waste; green points and arrows indicate a negative reinforcing effect, i.e., reduced food waste; other points and arrows illustrate contributing factors that lead to the respective effects. B1-Balancing Loop 1. B2-Balancing Loop 2.

The CLD includes many loops, most of which are balancing loops, because we focus on the analysis activities that will reduce a FoodWaste. The two most important loops for the purposes of this paper are from the HoReCa company's operations point of view.

Balancing Loop 1 (B1). Growing Sales increases IngredientsStocks, which creates the risk of increasing OutdatedFood. This then in turn will increase FoodWaste. In contrast, the increased FoodWaste consequently lowers the Sales volume. For this reason, there is a balancing loop. The main conclusion of this analysis is that in the case of planning to increase sales, more precise IngredientsStocks control mechanisms should be implemented first. Here, an implementation of selected lean tools (e.g., kanban) can be helpful. 
Balancing Loop 2 (B2). Growing Sales increases EdibleLeftovers, which contributes to increasing FoodWaste. This then in turn will decrease Sales. At the same time, in order to reduce EdibleLeftovers, they can be used as ReprocessedLeftovers, DonationsToCharity or StaffMeals, which will reduce FoodWaste. An important conclusion to be drawn from the analysis of such a loop is that by implementing ReprocessedLeftovers, DonationsToCharity or StaffMeals, we are not able to eliminate this type of FoodWaste-we are only able to reduce it. For this reason, from the company's point of view, it may be more important to analyze the reasons for the creation of EdibleLeftovers (e.g., on the basis of the Ishikawa chart) than to introduce reduction mechanisms for EdibleLeftovers.

The diagram presents a model that could be of interest to HoReCa businesses considering ways that food waste reduction creates a positive overall impact on sales and eventual profitability of their enterprise. Combining the knowledge of interrelated factors with the management practices can help a business set reasonable goals, such as space layouts and simplified menus to improve their operations. The CLD could be used to define a roadmap for program improvements. In applying the model, practitioners could see clear relations, analyze feedback loops, plan and coordinate their actions accordingly.

\subsection{Best Practices on the Macro Level}

Implementation of the 2030 Agenda relies on actions that take place mainly at the national and sub-national level [63]. Any analyses of SDG interdependencies that will influence policymaking need to take a macro perspective. The complexity that derives from these interdependencies and the aforementioned urgency to achieve change requires a trans-disciplinary process that combines research results with policymaking. Eventually, policymakers need a rubric for thinking systematically about the many interactions to support their identification of the stakeholders of a proposition; i.e., which groups will be allies and which ones require negotiation. To make coherent policies and strategies-beyond simply synergies and trade-offs - they need up-to-date empirical knowledge on how the goals and interventions of one sector affect another positively or negatively [64].

To achieve an effective implementation, executive acts, policies and strategies for achieving individual goals adopted at the international level are necessary [65]. Individual programs will then be implemented at the national level by involving regional and/or local authorities. Especially on national and international levels, the SDG perspective could be taken into account as an indirect support for FW reduction initiatives related to resource efficiency and circular economy, e.g., [66-68] [NDCs, Farm to Fork Strategy, Circular Economy Package]. Food waste reduction policy may be connected with environmental policy statements and environmental targets such as energy and transport efficiency and recycling of waste. Additionally, guidelines for consumers can encourage climatesmarter food choices, such as meat reduction or promotion of local food or considering the greenhouse gas emissions for food production (e.g., reduction of meat consumption and production). However, it is not just the environmental pillar that should be taken into account by stakeholders, but also the economic and social pillars.

Activities at the macro level are mainly carried out and coordinated alone or in alliances by public authorities, non-governmental organizations and other types of organizations, e.g., schools, universities, etc. Such activities can be divided into two areas: soft and hard (Figure 3).

Soft activities focus on increasing awareness among society members and representatives of various organizational entities: enterprises, business environment institutions, academia and secondary schools, e.g., promotion of good nutrition practices in secondary schools [57]. These activities can be divided into passive and active. Passive mainly concerns passive influence on recipients, e.g., information campaigns: leaflets, actions in multimedia and mass media. Active requires active action, commitment, implementation of desired behaviors, e.g., implementation of biodegradable dishes or food collection [19]. In practice, much better results or even a synergy result will be obtained through a mix of different policies, e.g., passive awareness, gamification or passive awareness and com- 
munity engagement provide a synergy effect of food waste reduction [46]. Soft actions should be initiated at the international and/or national levels, while regional and/or local authorities should be responsible for their implementation, as they have direct contact with society (people).

Macro level activities to decrease food waste in HoReCa

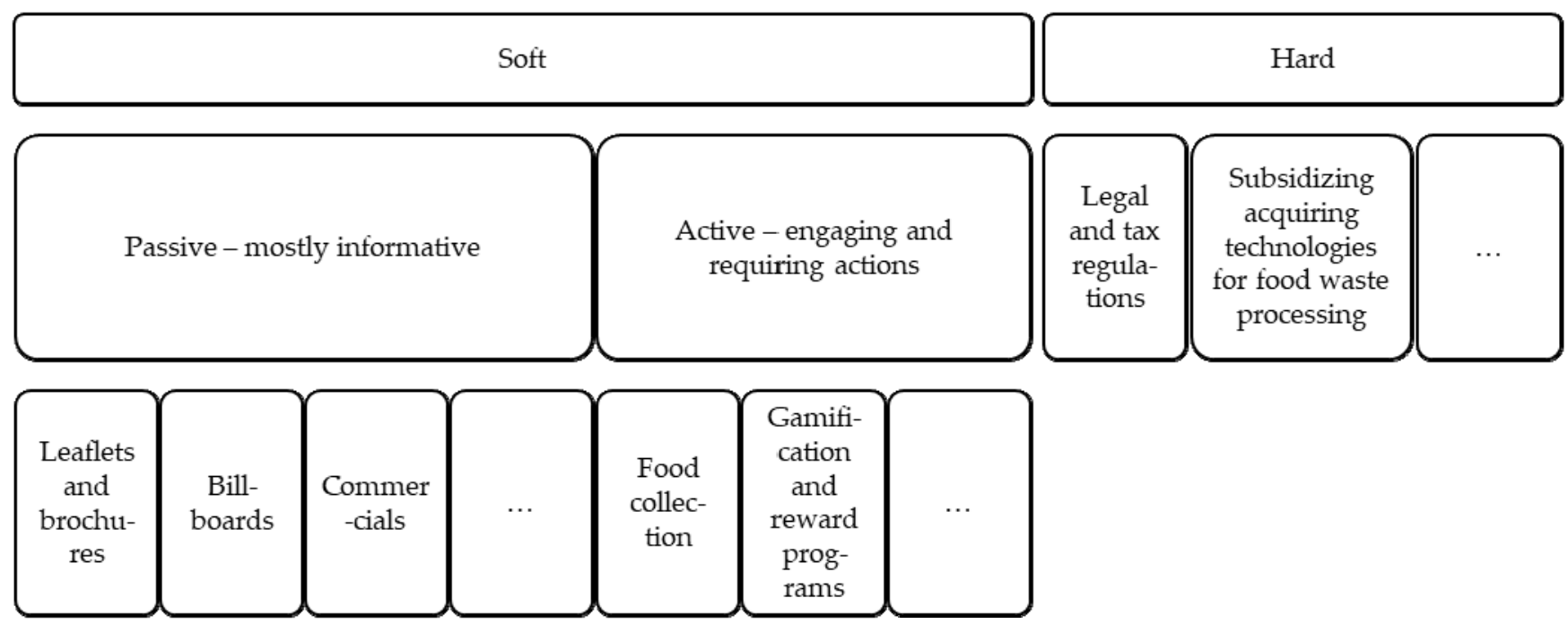

Figure 3. Types of actions for decrease of FW on macro level. Legend: “ .. "-hybrid or not defined activities.

Hard activities can be divided into: legal regulations, e.g., requiring the use of selected solutions in business and agricultural activities or a ban on the use of selected solutions or behaviors; tax regulations, e.g., introducing tax breaks for enterprises, including farms or VAT reductions; dedicated support programs, e.g., financial support for enterprises for the purchase of clean technologies. Most of the hard activities should be carried out by government administration.

Often authorities are implementing sets of soft and hard activities [29]. Activities dedicated to FW reduction usually address society and/ or people; companies, including HoReCa companies; science, research and technology development organizations; schools, including primary, secondary and high schools; other institutions, including chambers of commerce and public authorities.

\subsection{Analysis of the SDGs Related to Food Waste}

There are a number of publications in which the relations between individual SDGs in the context of FW were analyzed [39,42,43]. Pradhan et al. [69] analyzed the SDG interactions to identify the synergies and trade-offs between them. They classified a significant positive correlation between a pair of SDG indicators as a synergy, i.e., progress in one goal promotes progress in another. A significant negative correlation was classified as a trade-off where progress in one goal hinders progress in another. Most trade-offs relate to a nonsustainable development paradigm that focuses on economic growth to generate human welfare at the expense of the environment and natural resources. They uncovered some global patterns among the SDGs based on positive and negative correlations between indicator pairs. For example, in their analysis, SDG 1 (No poverty) has a synergistic relationship with most of the other goals, whereas SDG 12 (Responsible consumption and production) is the goal most commonly associated with trade-offs. Sustainable Development Goal 12 is identified as conflicting with most other SDGs and is thereby non-supportive of sustainable development. They found that SDG 12 has negative correlations with 10 goals (SDGs 1-7, 
9, 10, 17). Eventually, attainment of Agenda 2030 will greatly depend on whether synergies can be leveraged, and trade-offs identified and tackled.

As already indicated, Target 12.3 explicitly address the reduction of global food waste at retail and consumer levels and FW along production and supply chains. Malefors et al. [28] make a strong case for more robust measurements of current food waste statistics, without which it is not possible to ascertain that food waste has been halved. Additional targets that reinforce or are reinforced by 12.3 are given in (Table 4). However, this should not be considered as an exhaustive list of possible synergies or trade-offs.

Table 4. Relationships between Target 12.3 and additional targets of SDGs from a HoReCa perspective.

\begin{tabular}{|c|c|}
\hline Interdependent SDG Targets & $\begin{array}{l}\text { Rationale-Synergy, Trade-off or Both } \\
\text { with Relation to Target } 12.3\end{array}$ \\
\hline $\begin{array}{l}\text { 4.7-By 2030, ensure that all learners acquire the knowledge and skills needed to } \\
\text { promote sustainable development, including, among others, through education for } \\
\text { sustainable development and sustainable lifestyles. } \\
\text { 12.8-By 2030, ensure that people everywhere have the relevant information and } \\
\text { awareness for sustainable development and lifestyles in harmony with nature. } \\
\text { 13.3- Improve education, awareness-raising and human and institutional capacity on } \\
\text { climate change mitigation, adaptation, impact reduction and early warning. }\end{array}$ & $\begin{array}{l}\text { Synergy: addressing consumer and retail } \\
\text { food waste will require a re-education } \\
\text { and increased awareness of the } \\
\text { importance of food resources for both } \\
\text { local and global sustainability. }\end{array}$ \\
\hline $\begin{array}{l}\text { 8.2-Achieve higher levels of economic productivity through diversification, } \\
\text { technological upgrading and innovation, including through a focus on high-value } \\
\text { added and labor-intensive sectors. } \\
\text { 8.4-Improve progressively, through 2030, global resource efficiency in consumption } \\
\text { and production and endeavor to decouple economic growth from environmental } \\
\text { degradation, in accordance with the 10-Year Framework of Programs on Sustainable } \\
\text { Consumption and Production, with developed countries taking the lead. } \\
\text { 12.5-By 2030, substantially reduce waste generation through prevention, reduction, } \\
\text { recycling and reuse. }\end{array}$ & $\begin{array}{l}\text { Both: food waste reduction will require } \\
\text { the food service industries to look at } \\
\text { packaging, transportation, } \\
\text { and procedural innovations and } \\
\text { improvements across the entire food } \\
\text { value chain. }\end{array}$ \\
\hline $\begin{array}{l}\text { 2.4-By 2030, ensure sustainable food production systems and implement resilient } \\
\text { agricultural practices that increase productivity and production, that help maintain } \\
\text { ecosystems, that strengthen capacity for adaptation to climate change, extreme } \\
\text { weather, drought, flooding and other disasters and that progressively improve land } \\
\text { and soil quality. }\end{array}$ & $\begin{array}{l}\text { Both: if this target is addressed, } \\
\text { the availability of food will be secured, } \\
\text { but waste should still be reduced to } \\
\text { improve availability to the less } \\
\text { advantaged in society. }\end{array}$ \\
\hline $\begin{array}{l}\text { 11.6-By } 2030 \text {, reduce the adverse per capita environmental impact of cities, including } \\
\text { by paying special attention to air quality and municipal and other waste management. }\end{array}$ & $\begin{array}{l}\text { Synergy: addressing this target will not } \\
\text { reduce food waste, but it could help } \\
\text { ensure a proper handling of food and } \\
\text { other organic wastes. }\end{array}$ \\
\hline
\end{tabular}

These related targets reflect the observed asymmetry regarding FW within the food value chain. Developed countries have been found to be inclined to waste food later in the supply chain, whereas food waste in developing countries occurs early in the food chain [70]. In addition, there is also the problem of the severe imbalance between surplus food suitable for human consumption going to waste in the developed countries while people living in poverty (anywhere) or famine struck regions are unable to provide sufficient food. As an example, the topic of education broaches both the need for good research to provide the scientific foundations for sustainable agriculture or innovations in biodegradable packaging [71]. In addition, basic education worldwide is needed to increase the awareness of FW as a problem and provide advice on how to avoid FW in the home. HoReCa professionals will also benefit from sharing workable approaches to FW, such as those proposed by Secondi et al. [50] and based on research on food surplus redistribution reported by Galli et al. [72].

\subsection{Framework}

In general, all programs/activities are designed and tend to have a positive impact on FW reduction. However, additional research is needed to evaluate dependencies 
and impacts of specific programs and actions on FW reduction and other specific SDGs indirectly related to 12.3 .

The framework (Figure 4) shows the traceability of best practices on the micro level for SDGs according to the food waste reduction. The crucial role in this framework is to have public authorities, especially for national and regional levels. Programs launched by public authorities are usually defined as a set of actions that consist of soft and hard program elements.

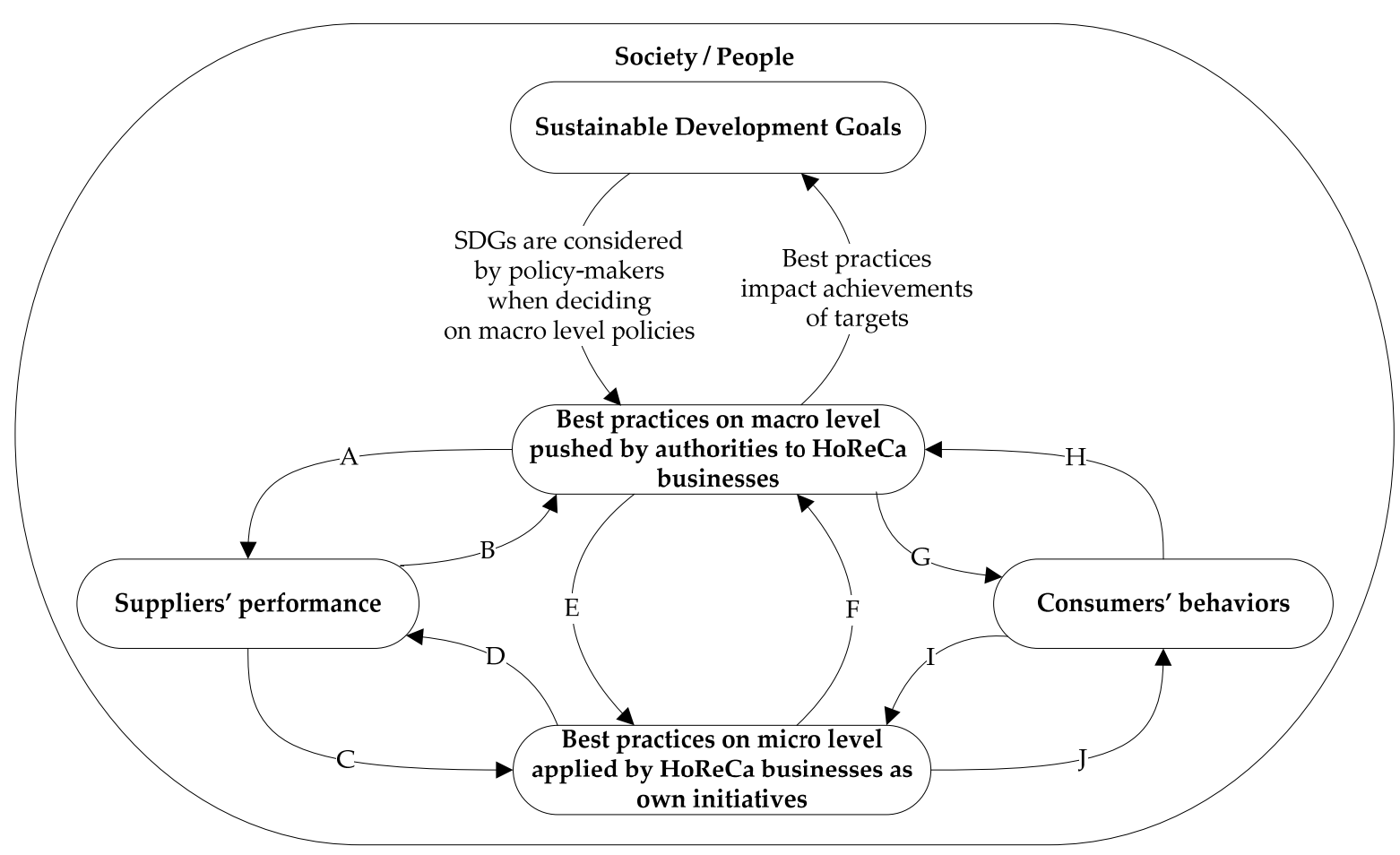

Figure 4. Conceptual causal loop diagram for SDG support from HoReCa best practices on food waste.

Legend:

A Programs launched by public authorities (regional, national and international levels) addressed to HoReCa suppliers have indirect influence on FW reduction by HoReCa sector.

B Suppliers' performance in terms of FW is considered by authorities when deciding on best practices on macro level.

C Suppliers' performance in term of FW drives their own decisions on best practices on the micro level.

D Available best practices on micro level and access to information about them affects suppliers' performance in terms of FW.

E Programs launched by authorities serve as guidelines for suppliers and consumers when thinking about best practices on the micro level.

F Available best practices on the micro level and access to information about serving for a bottom-up formulation of best practices on macro level by authorities.

G Programs launched by public authorities (regional, national and international levels) addressed to consumers, mainly related to awareness have indirect influence on FW reduction by HoReCa sector.

$\mathrm{H}$ Consumer behavior is considered by authorities when deciding on macro level policies.

I Consumer behavior is a driver for formulation of best practices (and worst as well) on micro level.

J Consumer' behavior is impacted by best available practices on micro level and information about them. 


\section{Discussion-Systems Engineering for SDGs in HoReCa}

The SDGs are a network of interconnected goals used as a reference for the international community in working towards sustainable development $[69,73,74]$. The interdependencies of the SDGs in HoReCa described above are presented in Table 4, but questions raised by this analysis are: why do these relationships between SDGs in HoReCa matter and what is the relevance of a systems engineering approach? In this study, we conducted a systematic literature review and used a systems engineering approach by applying systems thinking to these results in the context of the SDGs. The SDGs act as a large system made up of smaller systems [75], i.e., a system of systems. Recent critiques of the SDGs highlight the importance of these interdependencies. Spangenberg [76] found them to be weak on agency, while requiring little from governments and nothing from business or consumers. The SDGs focus on the state and impact, ignoring conflict and stakeholder knowledge of the issues [77,78], as well as the pressures and drivers that counteract each other in competing impact categories in the same or different geographic contexts [76].

These critiques show areas where systems engineering can contribute. Systems engineering is quite advanced in methods for stakeholder inclusivity, and including stakeholders in actions directed towards implementing these goals, will help address the criticisms listed by Spangenberg [76] and others. The systems engineering community, and by this we specifically call attention to the progress and initiatives of the International Council for Systems Engineering (INCOSE), is actively venturing into the social domain, where the technical and social systems are being addressed as one [79]. This inclusivity of not only stakeholders, but also non-traditional engineering domains, places systems engineering practices in a key position to develop an inclusive, representative approach that addresses these goals as a holistic system for HoReCa enterprises.

Meeting or attempting to find ways to implement the SDGs in HoReCa lends itself naturally towards systems engineering because the SDGs are easily framed in a systems theoretical context [80], and capacity building to meet SDGs has been argued to require systems thinking [81]. This is illustrated with Table 4 and Figure 4 in the context of HoReCa. System archetypes $[82,83]$ can be helpful to gain insight into patterns of behavior, especially in contexts of interconnected and competing goals [84]. In addition, SDGs intersect many societal domains, and a systems approach to investigating persistent social and environmental problems has been shown to help policymakers tackle the complexity associated with many intersected societal domains [85].

\section{Conclusions}

Food waste reduction should be analyzed holistically. It should be noted that there are many interdependencies between individual SDGs. These interdependencies should also be taken into account when policies, strategies and programs at the international, national, interregional, regional and local levels are defined. It requires a systemic approach not only with regard to the impact of one or more policies, but also considering the relationships between SDGs (also on sub-goal levels) which these policies address.

Author Contributions: Conceptualization, A.B. and B.G.; methodology, B.G., A.B. and E.P.; software, B.G. and A.B.; validation, A.B., B.G. and E.P.; formal analysis, A.B., B.G. and E.P.; investigation, A.B. and B.G.; resources, A.B. and B.G.; data curation, A.B. and B.G.; writing-original draft preparation, A.B. and B.G.; writing-review and editing, A.B., B.G. and E.P.; visualization, B.G. and A.B.; supervision, A.B. and B.G.; project administration, A.B. and B.G.; funding acquisition, A.B. and B.G. All authors have read and agreed to the published version of the manuscript.

Funding: The APC was covered from internal Warsaw University of Technology grant for management and quality sciences.

Institutional Review Board Statement: Not applicable.

Informed Consent Statement: Not applicable.

Data Availability Statement: Data available on request due privacy restrictions. 
Acknowledgments: Authors would like to thank Cecilia Haskins from Norwegian University of Science and Technology for substantial support during paper preparation.

Conflicts of Interest: The authors declare no conflict of interest.

\section{References}

1. Fu, B.; Wang, S.; Zhang, J.; Hou, Z.; Li, J. Unravelling the Complexity in Achieving the 17 Sustainable-Development Goals. Natl. Sci. Rev. 2019, 6, 386-388. [CrossRef]

2. Frank, A. Über Verwertung Der Küchenabfälle Für Gewinnung von Trockenfutter Und von Fett Durch Ausnutzung Der Abgehenden Hitze Der Gasanstalten, Sowie Anderer Industrieller Betriebe. J. Prakt. Chem. 1915, 92, 419-424. [CrossRef]

3. Brown, L.P. Food Wastes-Some Causes and Remedies. J. Frankl. Inst. 1918, 185, 585-610. [CrossRef]

4. Lau, W.; Cipani, E. Reducing Student Food Waste in a Cafeteria-Style Dining Setting through Contingency Management. Child Youth Care Forum 1983, 12, 301-310. [CrossRef]

5. Youngs, A.J.; Nobis, G.; Town, P. Food Waste from Hotels and Restaurants in the U.K. Waste Manag. Res. 1983, 1, 295-308. [CrossRef]

6. Gunders, D.; Bloom, J. Wasted: How America Is Losing up to 40 Percent of Its Food from Farm to Fork to Landfill; Natural Resources Defense Council: New York, NY, USA, 2017.

7. Stenmarck, Â.; Jensen, C.; Quested, T.; Moates, G.; Buksti, M.; Cseh, B.; Juul, S.; Parry, A.; Politano, A.; Redlingshofer, B. Estimates of European Food Waste Levels; IVL Swedish Environmental Research Institute: Stockholm, Sweden, 2016.

8. UN. The Sustainable Development Goals Report 2020; United Nations: New York, NY, USA, 2020; ISBN 978-92-1-004960-3. Available online: www.un-ilibrary.org (accessed on 10 April 2021).

9. Bloom, J. American Wasteland: How America Throws Away Nearly Half of Its Food; Da Capo Books: Cambridge, MA, USA, 2010.

10. Benton, D. Portion Size: What We Know and What We Need to Know. Crit. Rev. Food Sci. Nutr. 2015, 55, 988-1004. [CrossRef] [PubMed]

11. Stöckli, S.; Dorn, M.; Liechti, S. Normative Prompts Reduce Consumer Food Waste in Restaurants. Waste Manag. 2018, 77, 532-536. [CrossRef] [PubMed]

12. Lasek, A.; Cercone, N.; Saunders, J. Restaurant Sales and Customer Demand Forecasting: Literature Survey and Categorization of Methods. In Smart City 360 , Proceedings of the First EAI International Summit, Smart City 360 , Toronto, ON, Canada, 13-16 October 2015; Leon-Garcia, A., Lenort, R., Holman, D., Staš, D., Krutilova, V., Wicher, P., Cagáňová, D., Špirková, D., Golej, J., Nguyen, K., Eds.; Springer International Publishing: Cham, Switzerland, 2016; pp. 479-491.

13. Sirieix, L.; Lála, J.; Kocmanová, K. Understanding the Antecedents of Consumers' Attitudes towards Doggy Bags in Restaurants: Concern about Food Waste, Culture, Norms and Emotions. J. Retail. Consum. Serv. 2017, 34, 153-158. [CrossRef]

14. Papargyropoulou, E.; Steinberger, J.K.; Wright, N.; Lozano, R.; Padfield, R.; Ujang, Z. Patterns and Causes of Food Waste in the Hospitality and Food Service Sector: Food Waste Prevention Insights from Malaysia. Sustainability 2019, 11, 6016. [CrossRef]

15. UN. Global Indicator Framework for the Sustainable Development Goalsand Targets of the 2030 Agenda for Sustainable Development 2020; United Nations: New York, NY, USA, 2020.

16. Da Rosa, F.S.; Lunkes, R.J.; Spigarelli, F.; Compagnucci, L. Environmental Innovation and the Food, Energy and Water Nexus in the Food Service Industry. Resour. Conserv. Recycl. 2021, 166, 105350. [CrossRef]

17. Wang, L.-E.; Filimonau, V.; Li, Y. Exploring the Patterns of Food Waste Generation by Tourists in a Popular Destination. J. Clean. Prod. 2021, 279, 123890. [CrossRef]

18. Gładysz, B.; Buczacki, A.; Haskins, C. Lean Management Approach to Reduce Waste in Horeca Food Services. Resources 2020, 9, 144. [CrossRef]

19. De Visser-Amundson, A. A Multi-Stakeholder Partnership to Fight Food Waste in the Hospitality Industry: A Contribution to the United Nations Sustainable Development Goals 12 and 17. J. Sustain. Tour. 2020. [CrossRef]

20. Batlle-Bayer, L.; Bala, A.; Roca, M.; Lemaire, E.; Aldaco, R.; Fullana-i-Palmer, P. Nutritional and Environmental Co-Benefits of Shifting to "Planetary Health" Spanish Tapas. J. Clean. Prod. 2020, 271, 122561. [CrossRef]

21. Chinie, A.-C. Challenges for Reducing Food Waste. Proc. Int. Conf. Bus. Excell. 2020, 14, 819-828. [CrossRef]

22. Filimonau, V.; Todorova, E.; Mzembe, A.; Sauer, L.; Yankholmes, A. A Comparative Study of Food Waste Management in Full Service Restaurants of the United Kingdom and the Netherlands. J. Clean. Prod. 2020, 258, 120775. [CrossRef]

23. Vizzoto, F.; Tessitore, S.; Iraldo, F.; Testa, F. Passively Concerned: Horeca Managers' Recognition of the Importance of Food Waste Hardly Leads to the Adoption of More Strategies to Reduce It. Waste Manag. 2020, 107, 266-275. [CrossRef] [PubMed]

24. Okumus, B. How Do Hotels Manage Food Waste? Evidence from Hotels in Orlando, Florida. J. Hosp. Mark. Manag. 2020, 29, 291-309. [CrossRef]

25. Visschers, V.H.M.; Gundlach, D.; Beretta, C. Smaller Servings vs. Information Provision: Results of Two Interventions to Reduce Plate Waste in Two University Canteens. Waste Manag. 2020, 103, 323-333. [CrossRef]

26. Li, Y.; Wang, L.; Cheng, S. Spatiotemporal Variability in Urban HORECA Food Consumption and Its Ecological Footprint in China. Sci. Total Environ. 2019, 687, 1232-1244. [CrossRef] [PubMed]

27. Filimonau, V.; Fidan, H.; Alexieva, I.; Dragoev, S.; Marinova, D.D. Restaurant Food Waste and the Determinants of Its Effective Management in Bulgaria: An Exploratory Case Study of Restaurants in Plovdiv. Tour. Manag. Perspect. 2019, $32,100577$. [CrossRef] 
28. Malefors, C.; Callewaert, P.; Hansson, P.-A.; Hartikainen, H.; Pietiläinen, O.; Strid, I.; Strotmann, C.; Eriksson, M. Towards a Baseline for Food-Waste Quantification in the Hospitality Sector-Quantities and Data Processing Criteria. Sustainability 2019, 11, 3541. [CrossRef]

29. Chalak, A.; Abou-Daher, C.; Abiad, M.G. Generation of Food Waste in the Hospitality and Food Retail and Wholesale Sectors: Lessons from Developed Economies. Food Secur. 2018, 10, 1279-1290. [CrossRef]

30. Martin-Rios, C.; Demen-Meier, C.; Gössling, S.; Cornuz, C. Food Waste Management Innovations in the Foodservice Industry. Waste Manag. 2018, 79, 196-206. [CrossRef]

31. Filimonau, V.; Krivcova, M. Restaurant Menu Design and More Responsible Consumer Food Choice: An Exploratory Study of Managerial Perceptions. J. Clean. Prod. 2017, 143, 516-527. [CrossRef]

32. Iraldo, F.; Testa, F.; Lanzini, P.; Battaglia, M. Greening Competitiveness for Hotels and Restaurants. J. Small Bus. Enterp. Dev. 2017, 24, 607-628. [CrossRef]

33. Pirani, S.I.; Arafat, H.A. Reduction of Food Waste Generation in the Hospitality Industry. J. Clean. Prod. 2016, 132, 129-145. [CrossRef]

34. Falasconi, L.; Vittuari, M.; Politano, A.; Segrè, A. Food Waste in School Catering: An Italian Case Study. Sustainability 2015, 7, 14745-14760. [CrossRef]

35. Ananno, A.A.; Masud, M.H.; Chowdhury, S.A.; Dabnichki, P.; Ahmed, N.; Arefin, A.M.E. Sustainable Food Waste Management Model for Bangladesh. Sustain. Prod. Consum. 2021, 27, 35-51. [CrossRef]

36. Adelodun, B.; Kim, S.H.; Choi, K.-S. Assessment of Food Waste Generation and Composition among Korean Households Using Novel Sampling and Statistical Approaches. Waste Manag. 2021, 122, 71-80. [CrossRef]

37. Antón-Peset, A.; Fernandez-Zamudio, M.-A.; Pina, T. Promoting Food Waste Reduction at Primary Schools. A Case Study. Sustainability 2021, 13, 600. [CrossRef]

38. Pateman, R.M.; de Bruin, A.; Piirsalu, E.; Reynolds, C.; Stokeld, E.; West, S.E. Citizen Science for Quantifying and Reducing Food Loss and Food Waste. Front. Sustain. Food Syst. 2020, 4, 589089. [CrossRef]

39. Feijoo, G.; Moreira, M.T. Fostering Environmental Awareness towards Responsible Food Consumption and Reduced Food Waste in Chemical Engineering Students. Educ. Chem. Eng. 2020, 33, 27-35. [CrossRef]

40. Amicarelli, V.; Bux, C. Food Waste in Italian Households during the Covid-19 Pandemic: A Self-Reporting Approach. Food Secur. 2021, 13, 25-37. [CrossRef] [PubMed]

41. You, F.; Bhamra, T.; Lilley, D. Why Is Airline Food Always Dreadful? Analysis of Factors Influencing Passengers' Food Wasting Behaviour. Sustainability 2020, 12, 8571. [CrossRef]

42. Fattibene, D.; Recanati, F.; Dembska, K.; Antonelli, M. Urban Food Waste: A Framework to Analyse Policies and Initiatives. Resources 2020, 9, 99. [CrossRef]

43. Fleetwood, J. Social Justice, Food Loss, and the Sustainable Development Goals in the Era of COVID-19. Sustainability 2020, 12, 5027. [CrossRef]

44. Eriksson, M.; Malefors, C.; Bergström, P.; Eriksson, E.; Osowski, C.P. Quantities and Quantification Methodologies of Food Waste in Swedish Hospitals. Sustainability 2020, 12, 3116. [CrossRef]

45. Kasza, G.; Dorkó, A.; Kunszabó, A.; Szakos, D. Quantification of Household Food Waste in Hungary: A Replication Study Using the FUSIONS Methodology. Sustainability 2020, 12, 3069. [CrossRef]

46. Soma, T.; Li, B.; Maclaren, V. Food Waste Reduction: A Test of Three Consumer Awareness Interventions. Sustainability 2020, 12, 907. [CrossRef]

47. Leverenz, D.; Moussawel, S.; Maurer, C.; Hafner, G.; Schneider, F.; Schmidt, T.; Kranert, M. Quantifying the Prevention Potential of Avoidable Food Waste in Households Using a Self-Reporting Approach. Resour. Conserv. Recycl. 2019, 150, 104417. [CrossRef]

48. Caldeira, C.; De Laurentiis, V.; Corrado, S.; van Holsteijn, F.; Sala, S. Quantification of Food Waste per Product Group along the Food Supply Chain in the European Union: A Mass Flow Analysis. Resour. Conserv. Recycl. 2019, 149, 479-488. [CrossRef] [PubMed]

49. Nicholes, M.J.; Quested, T.E.; Reynolds, C.; Gillick, S.; Parry, A.D. Surely You Don't Eat Parsnip Skins? Categorising the Edibility of Food Waste. Resour. Conserv. Recycl. 2019, 147, 179-188. [CrossRef]

50. Secondi, L.; Principato, L.; Mattia, G. Can Digital Solutions Help in the Minimization of Out-of-Home Waste? An Analysis from the Client and Business Perspective. Br. Food J. 2019, 122, 1341-1359. [CrossRef]

51. Wakiyama, T.; Lenzen, M.; Faturay, F.; Geschke, A.; Malik, A.; Fry, J.; Nansai, K. Responsibility for Food Loss from a Regional Supply-Chain Perspective. Resour. Conserv. Recycl. 2019, 146, 373-383. [CrossRef]

52. Pollard, C.M.; Booth, S. Food Insecurity and Hunger in Rich Countries-It Is Time for Action against Inequality. Int. J. Environ. Res. Public Health 2019, 16, 1804. [CrossRef]

53. Lassen, A.D.; Christensen, L.M.; Spooner, M.P.; Trolle, E. Characteristics of Canteens at Elementary Schools, Upper Secondary Schools and Workplaces That Comply with Food Service Guidelines and Have a Greater Focus on Food Waste. Int. J. Environ. Res. Public Health 2019, 16, 1115. [CrossRef]

54. Reynolds, C.; Goucher, L.; Quested, T.; Bromley, S.; Gillick, S.; Wells, V.K.; Evans, D.; Koh, L.; Carlsson Kanyama, A.; Katzeff, C.; et al. Review: Consumption-Stage Food Waste Reduction Interventions-What Works and How to Design Better Interventions. Food Policy 2019, 83, 7-27. [CrossRef] 
55. Cooper, J. Briefing: Food Waste-Next Steps for Food Processors and Manufacturers. Proc. Inst. Civ. Eng. Waste Resour. Manag. 2018, 171, 91-93. [CrossRef]

56. Corrado, S.; Sala, S. Food Waste Accounting along Global and European Food Supply Chains: State of the Art and Outlook. Waste Manag. 2018, 79, 120-131. [CrossRef]

57. Kowalewska, M.T.; Kołłajtis-Dołowy, A. Food, Nutrient, and Energy Waste among School Students. Br. Food J. 2018, 120, 1807-1831. [CrossRef]

58. Tjarnemo, H.; Sodahl, L. Swedish Food Retailers Promoting Climate Smarter Food Choices-Trapped between Visions and Reality? J. Retail. Consum. Serv. 2015, 24, 130-139. [CrossRef]

59. Clowes, A.; Hanson, C.; Swanell, R. The Business Case for Reducing Food Loss and Waste: Restaurants. Champions 12.3.2019. Available online: www.champions123.org (accessed on 10 April 2021).

60. De Steur, H.; Wesana, J.; Dora, M.K.; Pearce, D.; Gellynck, X. Applying Value Stream Mapping to Reduce Food Losses and Wastes in Supply Chains: A Systematic Review. Waste Manag. 2016, 58, 359-368. [CrossRef] [PubMed]

61. Morecroft, J. Strategic Modelling and Business; John Wiley \&Sons: Chichester, UK; Hoboken, NJ, USA, 2007; ISBN 978-0-470-01286-4.

62. Sterman, J.D. System Dynamics Modeling: Tools for Learning in a Complex World. Calif. Manag. Rev. 2001, 43, 8-25. [CrossRef]

63. Breuer, A.; Janetschek, H.; Malerba, D. Translating Sustainable Development Goal (SDG) Interdependencies into Policy Advice. Sustainability 2019, 11, 2092. [CrossRef]

64. Nilsson, M.; Griggs, D.; Visbeck, M. Policy: Map the Interactions between Sustainable Development Goals. Nat. News 2016, 534, 320. [CrossRef]

65. EC. Closing the Loop-An EU Action Plan for the Circular Economy COM/2015/0614 Final—European Environment Agency. Available online: https:/ /www.eea.europa.eu/policy-documents/com-2015-0614-final (accessed on 8 April 2021).

66. EC. Report from the Commission to the European Parliament, the Council COM/2019/190 Final-The European Economic and Social Committee and the Committee of the Regions on the Implementation of the Circular Economy Action Plan. Available online: https: / / eur-lex.europa.eu/legal-content/pl/TXT/?uri=CELEX:52019DC0190 (accessed on 10 April 2021).

67. EC. Farm to Fork Strategy. For a Fair, Healthy and Environmentally-Friendly Food System. Available online: https://ec.europa. eu/food/farm2fork_en (accessed on 10 April 2021).

68. UN. Nationally Determined Contributions under the Paris Agreement. Synthesis Report by the Secretariat, UN. Available online: https://unfccc.int/process-and-meetings/the-paris-agreement/nationally-determined-contributions-ndcs/nationallydetermined-contributions-ndcs (accessed on 10 April 2021).

69. Pradhan, P.; Costa, L.; Rybski, D.; Lucht, W.; Kropp, J.P. A Systematic Study of Sustainable Development Goal (SDG) Interactions. Earth's Future 2017, 5, 1169-1179. [CrossRef]

70. Gustavsson, J.; Cederberg, C.; Sonesson, U.; Van Otterdijk, R.; Meybeck, A. FAO Global Food Losses and Food Waste-Extent, Causes and Prevention; Technical Report; FAO: Rome, Italy; Swedish Institute for Food and Biotechnology (SIK): Göteborg, Sweden, 2011.

71. Bergman, Z.; Bergman, M.M.; Fernandes, K.; Grossrieder, D.; Schneider, L. The Contribution of UNESCO Chairs toward Achieving the UN Sustainable Development Goals. Sustainability 2018, 10, 4471. [CrossRef]

72. Galli, F.; Cavicchi, A.; Brunori, G. Food Waste Reduction and Food Poverty Alleviation: A System Dynamics Conceptual Model. Agric. Hum. Values 2019, 36, 289-300. [CrossRef]

73. Blanc, D.L. Towards Integration at Last? The Sustainable Development Goals as a Network of Targets. Sustain. Dev. 2015, 23, 176-187. [CrossRef]

74. UN. Resolution Adopted by the General Assembly on 25 September 2015. Transforming Our World: The 2030 Agenda for Sustainable Development 2015; United Nations: New York, NY, USA, 2015.

75. Palmer, E.; Burton, R.; Haskins, C. A Systems Engineering Framework for Bioeconomic Transitions in a Sustainable Development Goal Context. Sustainability 2020, 12, 6650. [CrossRef]

76. Spangenberg, J.H. Hot Air or Comprehensive Progress? A Critical Assessment of the SDGs. Sustain. Dev. 2017, 25, 311-321. [CrossRef]

77. Wong, R.; van der Heijden, J. Avoidance of Conflicts and Trade-Offs: A Challenge for the Policy Integration of the United Nations Sustainable Development Goals. Sustain. Dev. 2019, 27, 838-845. [CrossRef]

78. Sanz-Hernández, A.; Esteban, E.; Garrido, P. Transition to a Bioeconomy: Perspectives from Social Sciences. J. Clean. Prod. 2019, 224, 107-119. [CrossRef]

79. Palmer, E.; Rhodes, D.; Watson, M.; Haskins, C.; Olaya, C.; Presland, I.; Fossum, K. Putting the Social in Systems Engineering: An Overview and Conceptual Development; INCOSE: San Diego, CA, USA, 2021; in press.

80. Skene, K.R.; Malcolm, J. Using the SDGs to Nurture Connectivity and Promote Change. Des. J. 2019, 22, 1629-1646. [CrossRef]

81. Stafford-Smith, M.; Griggs, D.; Gaffney, O.; Ullah, F.; Reyers, B.; Kanie, N.; Stigson, B.; Shrivastava, P.; Leach, M.; O'Connell, D. Integration: The Key to Implementing the Sustainable Development Goals. Sustain. Sci. 2017, 12, 911-919. [CrossRef] [PubMed]

82. Senge, P.M. The Fifth Discipline Fieldbook: Strategies and Tools for Building a Learning Organization; Currency, Doubleday: New York, NY, USA, 1994; ISBN 978-0-385-47256-2.

83. Braun, W. The System Archetypes. System 2002, 1, 1-26.

84. Wolstenholme, E. Using Generic System Archetypes to Support Thinking and Modelling. Syst. Dyn. Rev. 2004, 20, 341-356. [CrossRef]

85. Probst, G.; Bassi, A.M. Tackling Complexity; Routledge: London, UK, 2014. 